\title{
Pulmoner Tromboemboli Şüphesi Olan Hastalarda Derin Ven Trombozu Tanısında İndirekt Bilgisayarlı Tomografi Venografi ile Renkli Doppler Ultrasonografi Bulgularının Karşılaştırılması
}

\section{The Comparison of Color Doppler Ultrasonography and Indirect Computer Tomography Venography for the Diagnosis of Deep Venous Thrombosis in Patients with Suspected Pulmonary Thromboembolism}

\author{
Betül GÜNEY ${ }^{1}$, Mustafa GÜLEÇ
}

\author{
${ }^{1}$ Kayseri Melikgazi Hospital, Radiology Clinic, Kayseri, Turkey \\ ${ }^{2}$ Erciyes University, Faculty of Medicine, Department of Radiology, Kayseri, Turkey
}

Geliş tarihi: 20.01.2020 Kabul tarihi: 09.06.2020 DOI: 10.17517/ksutfd.673979

\begin{abstract}
Özet
Amaç: Tekrarlayan pulmoner tromboembolizmde derin ven trombozu (DVT) tanısını koymak önemlidir. DVT tanısının atlanması Pulmoner Emboli (PE) tedavisinde yetersizliğe yol açar. Bu yüzden PE tedavisinde DVT tespiti kritik öneme sahiptir. Bu çalışmanın amacı, Pulmoner Tromboemboli (PTE) şüphesi olan hastalarda derin ven trombozu değerlendirmesi için Renkli Doppler Ultrasonografi (RDUS) ve İndirekt Bilgisayarlı Tomografi Venografi (İBTV) sonuçlarını karşılaştırmak ve İBTV’nin RDUS’a alternatif bir metod olup olmadığını araştırmaktır.

Gereç ve Yöntemler: Erciyes Üniversitesi Tip Fakültesi’nde Kasım 2007-Aralık 2009 tarihleri arasında klinik değerlendirme ile Pulmoner Emboli (PE) tanısı alan toplam 205 hasta çalışmaya dahil edildi. Pulmoner Bilgisayarlı Tomografi Anjiyografi (BTA) ve İBTV incelemeleri aynı seansta yapıldı. Pulmoner BTA incelemesinde kullanılan kontrast maddeye ilave kontrast madde verilmeden üç dakika sonra İBTV incelemesi yapıldı. Pulmoner BTA’ dan sonraki iki gün içerisinde alt ekstremite RDUS incelemesi yapildı.

Bulgular: Toplam 205 hastanın 84'ünde BTA'da PE, 45’inde ise PE'si olsun yada olmasın İBTV'de DVT saptandı. 84 hastanın 34'ünde PE ve DVT aynı anda gözlendi. 45 hastanın 38'i her iki yöntemle de DVT tanısı aldı. Yedi hasta sadece İBTV ile altı hasta ise sadece RDUS ile trombüs saptand.

Sonuç: Ultrasonografi ile kıyaslandığında Pulmoner BTA' ya BT Venografinin ilave edilmesi DVT tanısında yeterli olarak değerlendirildi. BTA anjiografi ve Venografinin kombine kullanımı seçili hastalarda daha yeterli olabileceği düşünülmüştür. Anahtar kelimeler: Pulmoner tromboemboli, Derin ven trombozu, İndirekt bilgisayarlı tomografi venografi, Renkli doppler ultrasonografi
\end{abstract}




\section{Abstract}

Objective: The diagnosis of deep venous thrombosis (DVT) is important for recurrent pulmonary thromboembolism (PTE). Missing the diagnosis of DVT leads to insufficiency in the treatment of Pulmonary Embolism (PE). Therefore, the detection of DVT is being critical in the treatment of PE. The purpose of the study is to compare Color Doppler Ultrasonography (CDUS), and Indirect Computer Tomography Venography (ICTV) results for the evaluation of deep venous thrombosis in patients with suspected Pulmonary Thromboembolism and to investigate whether ICTV is an alternative method to CDUS.

Materials and Methods:A total of 205 patients who were diagnosed as Pulmonary Embolism (PE) by clinical evaluation between November 2007 and December 2009 in Erciyes University Faculty of Medicine were included in the study. Pulmonary Computed Tomography Angiography (CTA) and ICTV examinations were performed in the same session. ICTV images were performed without further contrast material injection with three minutes delay after the beginning of the contrast injection for Pulmonary CTA. Lower extremity CDUS examination was performed within two days after the pulmonary CTA.

Results: Of 205 patients, 84 of the BTA had PE and 45 had a DVT (PE with or without) detected in ICTV. In 34 of 84 patients, $\mathrm{PE}$ and DVT were observed simultaneously. Thirty eight of 45 patients were diagnosed with DVT by both method. Thrombus was detected in seven patients with only ICTV and six with CDUS only.

Conclusion: Compared with sonography, ICTV, in addition to CT pulmonary angiography, is a relatively accurate method for the evaluation of DVT. It has been considered that Combined CT angiography and venography may be more efficacious than sonography in selected patients.

Keywords: Pulmonary thromboembolism, Deep vein thrombosis, Indirect computer tomography Venography, Color doppler ultrasonography

Yazışma Adresi: Betül GÜNEY Kayseri Melikgazi Hospital, Radiology Clinic, Kayseri, Turkey Telefon: 05335600605 e-mail: betulguney@ erciyes.edu.tr ORCID No (Sirasiyla): 0000-0001-9378-0912; 0000-0001-5894-4977 


\section{INTRODUCTION}

Pulmonary embolism (PE) is a feared complication of deep vein thrombosis (DVT), both of which are considered different components of the same disease. DVT is one of the most common preventable causes of death in hospitalized patients $(1,2)$. DVT and PE occur in approximately 300.000 to 600.000 patients each year in the United States, with approximately 50.000 deaths due to PE.Because of high mortality and morbidity, PE is difficult to diagnose and treat(3).

Thrombi of the veins in the lower extremitiescause $90 \%$ of PE. The primary prognostic factor in recurrent thromboembolism is residual thrombi in the proximal veins(4).DVT is often asymptomatic. Missing the diagnosis of recurrent DVT leads to insufficiency in the treatment of PE. Therefore, the detection of DVT is critical in the treatment of PE (5).

Nowadays, the first imaging modality in the diagnosis of PE is accepted as Computed Tomography Angiography (CTA). In recent years, indirect CT venography (ICTV), which is an alternative, fast and applicable method to RDUS, has been used in the evaluation of DVT(5). After pulmonary CTA with ICTV, the subdiaphragmatic deep venous system is imaged without additional contrast material. Lower extremity CDUS examination was performed within two days after the pulmonary CTA.

The present studyaims to compare the results of ICTV and CDUS in the diagnosis of DVT in patients with suspected PE.

\section{MATERIALS AND METHODS}

\section{Study design and setting}

The study was carried out at the Department of Radiology, faculty of medicine, Erciyes University. The study was approved by the Ethic Committee of Erciyes University (2008/166).

\section{Radiological examination}

CTA and ICTV examinations were performed with a 16 detector CT (GE @ Light Speed 16 Milwaukee, Wisconsin, USA). In pulmonary CTA, a bolus-tracking technique was used to provide contrast optimization in the pulmonary artery. In this technique, the first image was obtained for determining the main pulmonary artery level. In the supine position, a $100 \mathrm{ml}$ nonionic contrast agent $(300 \mathrm{mgI} / \mathrm{ml})$ was administered via the antecubital vein intraket through an automatic syringe at a rate of $3.5 \mathrm{ml} / \mathrm{s}$. Serial images were taken at a low dose $(40 \mathrm{~mA})$ at three-second intervals. When the contrast intensity in the pulmonary artery reached a sufficient density value $(100 \mathrm{HU})$, the table was brought to the starting point and cross-sectional images were taken. The patient took a short break during this procedure. The patient's arms were positioned on the upper part of the head to avoid artifact formation. Section images were taken from the lung apex to the diaphragm level $(16-25 \mathrm{~cm})$ to include the up- per-liver segments. Section thickness was $3.75 \mathrm{~mm}$ and reshaped by $1.25 \mathrm{~mm}$ reconstruction. The pitch value was set to $1.375: 1$. X-ray dose was determined as $120 \mathrm{kV}, 130 \mathrm{~mA}$. Collimation was $20 \mathrm{~mm}$, the table speed was $27.50 \mathrm{~mm} /$ rotation, and the scanning time was $7.2 \mathrm{sec}$. Helical scanning was performed with 16 detectors (16x1.25).

At the end of the pulmonary CTA examination, the patient remained on the tablefor 180 seconds, and images were obtained without any additional contrast agent. The sections included a region starting from iliac crest to distal to the popliteal fossa. The scanning of the section images was adjusted upward from the popliteal region. The cross-sectional distance was $4 \mathrm{~cm}$, and the cross-sectional thickness was $10 \mathrm{~mm}$. X-ray dose was determined as $120 \mathrm{kV}, 40 \mathrm{~mA}$. The collimation was $20 \mathrm{~mm}$ and the time of exposure was 11.2 sec.Axial scanning was with eight detectors $(8 \times 2.5)$ and the images were transferred to the PACS (Picture Archive and Communication System).

Pulmonary CTA was evaluated by a specialist radiologist. The filling defect in the pulmonary artery was determined as diagnostic criteria for PE. Hypo dense filling defect in venous structures on ICTV was the main diagnostic criterion for DVT. Extension of venous structures, linear density increase in perivenular fatty tissue, staining of vein walls, and lack of segmental staining were determined as auxiliary diagnostic criteria for DVT.

Lower extremity CDUS examination was performed within two days after the pulmonary CTA. The sonographic examination was performed with Toshiba Aplio CDUS devices. All CDUS examinations were evaluated by a radiologist who was unaware of the results of the ICTV. The Transducer was selected depending on the examined areaand the severity of edema in the patient's leg.A $3.75 \mathrm{MHz}$ convex probe was used in the pelvic region, and a $7.5 \mathrm{MHz}$ linear probe was used in the thigh and leg. A sonographic examination was performed from the distal segment of the inferior vena cava to the level of the popliteal vein trifurcation. The main femoral vein, the large saphenous vein junction, the proximal, middle and distal superficial femoral vein, the deep femoral vein, and the popliteal vein were routinely examined.

Evaluation of DVT with CDUS was performed in two stages. First, the gray structure of the veins was evaluated for wall structure, intra-lumen echogenicity, vessel diameter, response to compression, and diameter changes with respiration. Vein compressibility was evaluated mainly by transverse images. Any abnormal condition observed in the transverse plane was confirmed by images in the longitudinal plane. Doppler signals and response to augmentation were also investigated in the longitudinal plane. The second evaluation stage of DVT evaluated color fillings and flow forms. The presence of thrombus in CDUS, absence of flow in venous structures, decreased calibration, no compression, and no response to augmentation were the diagnostic criteria for DVT. In the presence of DVT, thrombus localization, throm- 
bus age, extension, recanalization and the presence of collateral structures were also evaluated. According to the last diagnosis, the efficacy of ICTV and CDUS in the diagnosis of DVT and whether they had superiorities or deficiencies compared to each other were investigated.

\section{Inclusion and Exclusion Criteria}

Exclusion criteria were patients with renal failure, patients with contrast agent allergy, pregnancy status, and pregnancy suspicion.The Wells Criteria is the most widely used and accepted method for optimizing DVT detection and cost in high-risk patients (6).

\section{Statistical Analysis}

All statistical data of the patients included in the study were evaluated with SPSS 11.0 Windows program (SPSS Inc. Chicago, Illinois). The McNemar's test was used to evaluate the difference between the two methods. The compatibility between the two methods was evaluated using the Kappa test. The sensitivity and specificity values of ICTV and CDUS findings and diagnostic criteria in ICTV were calculated. The level of significance was taken as 0.05 .

\section{RESULTS}

The study included 205 patients; 84 (40.9\%) had PE, 45 (24.8\%) had DVT on ICTV. Thirty-four had DVT, and only 50 had PE. Of these 84 patients with PE, isolated DVT was detected in 11 of 45 patients (Table $\mathbf{1}$ ).
Of the 45 patients who had DVT on ICTV, 38 had DVT on CDUS. Thirty-eight patients were diagnosed as DVT in both ICTV and CDUS. Seven patients with normal CDUS were diagnosed with DVT on ICTV, while six patients with normal DVT were diagnosed with DVT (Table 2). PE was detected in CTA in two patients who were diagnosed as DVT by CDUS, although they were not observed on ICTV. PE was present in all six patients diagnosed with DVT on ICTV, although they were not observed in CDUS. DVT was diagnosed in 38 of $84 \mathrm{PE}$ patients by both imaging methods.No DVT was detected in both IBTV and RDUS in 149 patients (Table 2).

Of the six patients diagnosed with DVT alone, four had no embolism, and two had embolism (Table 2). The results of ICTV and CDUS were compared. There was no statistically significant difference between the two methods ( $\mathrm{p}=0.97$ ). The compatibility of both methods was found to be significant $(\mathrm{p}=0.01)$.

There were 34 patients with PE and DVT. Three of these patients had bilateral DVT and bilateral PE. Two of these patients were diagnosed by ICTV, and one of them was diagnosed by CDUS (Table 3 ).

The main diagnostic criterion in ICTV was the intraluminal filling defect, and all criteria, including diameter increase, wall enhancement, and perivenular inflammation, were compared with RDUS (Table 4). Sensitivity, specificity, positive predictive value and negative predictive values were determined.

\section{Table 1. Results of IBTV and Pulmonary CTA}

\begin{tabular}{|l|l|l|l|}
\hline $\begin{array}{l}\text { CTA } \\
\text { ICTV }\end{array}$ & $\begin{array}{l}\text { PE (+) } \\
\mathbf{n} \%\end{array}$ & $\begin{array}{l}\text { PE(-) } \\
\mathbf{n} \%\end{array}$ & $\begin{array}{l}\text { Total } \\
\mathbf{n} \%\end{array}$ \\
\hline DVT(+) & $34(16.6)$ & $11(5.4)$ & $45(22)$ \\
\hline DVT(-) & $50(24.4)$ & $110(53.6)$ & $160(78)$ \\
\hline Total & $84(41)$ & $121(59)$ & 205 \\
\hline
\end{tabular}

Table 2. Results of ICTV and CDUSG

\begin{tabular}{|l|l|l|l|}
\hline Parameter & $\begin{array}{l}\text { CDUS (+) } \\
\mathbf{n} \%\end{array}$ & $\begin{array}{l}\text { CDUS (-) } \\
\mathbf{n} \%\end{array}$ & $\begin{array}{l}\text { Total } \\
\mathbf{n} \%\end{array}$ \\
\hline ICTV (+) & $38(18.6)$ & $7(3.4)$ & $45(22)$ \\
\hline ICTV (-) & $6(2.9)$ & $154(75.1)$ & $160(78)$ \\
\hline Total & $44(21.5)$ & $161(78.5)$ & 205 \\
\hline
\end{tabular}




\begin{tabular}{l|l|l|l|} 
Table 3. PE and DVT relationship & Right PE & Left PE & Bilateral PE \\
\hline Right DVT & 7 & 2 & 8 \\
\hline Left DVT & 3 & 2 & 9 \\
\hline Bilateral DVT & - & - & 3 \\
\hline
\end{tabular}

Table 4. Defect (D) + Wall enhancement (WE) + Diameter increase (DI) + Perivenular inflammation (PI) Relationship with DVT

\begin{tabular}{|l|l|l|l|l|}
\hline İCTV/CDUS & DVT (+) & DVT (-) & Total & Sensitivity:20.45 \% \\
\hline D +WE + PI+ DI (+) & 9 & 0 & 9 & Specificity: $100 \%$ \\
\hline D +WE + PI+ DI (-) & 35 & 161 & 196 & PPD: $100 \%$ \\
\hline Total & 44 & 161 & 295 & NPD: $82.14 \%$ \\
\hline
\end{tabular}
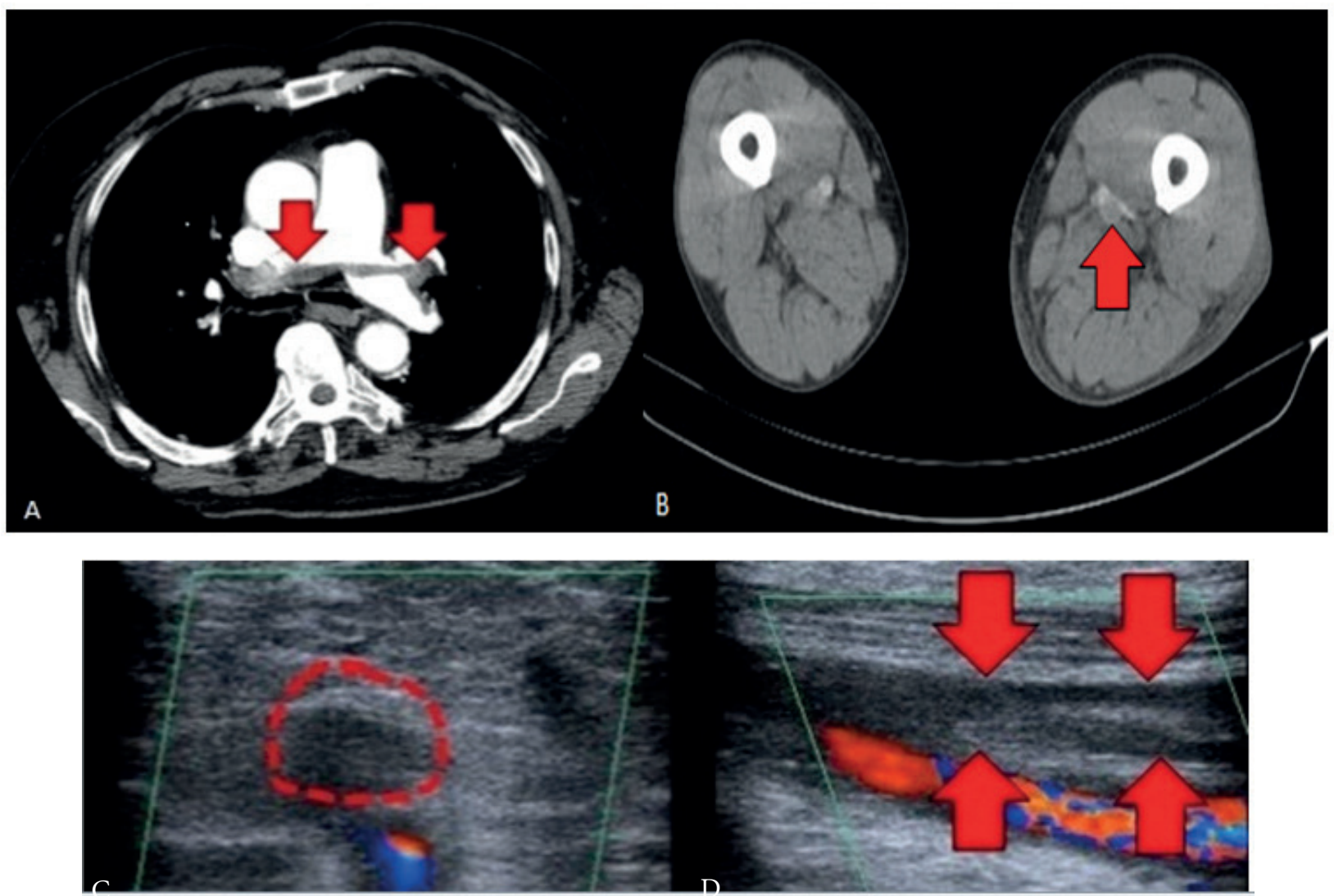

Figure 1. A 76-year-old male patient presented to the emergency department with respiratory distress.

A:In CTA, filling defects in both main pulmonary arteries consistent with embolism extending to the distal branches in shape are observed.

B:CTV shows increased diameter in the left popliteal vein, filling defects consistent with thrombus, and diameter increase.

C,D:CDUS has a hyperechoic appearance consistent with thrombus. 


\section{DISCUSSION}

Because of DVT asymptomatic course, recurrent DVT can lead to inadequate treatment of PE and may cause a life-threatening situation if DVT cannot be diagnosed (7). The most commonly used invasive test for adiagnosis of $\mathrm{PE}$ is $\mathrm{V}-\mathrm{P}$ scintigraphy.DVT is detected in $90 \%$ of patients with ahigh probability of V-P scintigraphy. However, more than $70 \%$ of patients have a low or moderate probability in V-P scintigraphy. Therefore, other imaging methods are needed $(8,9)$.

Although pulmonary CTA is not an invasive method like Conventional Pulmonary Angiography, it shows the presence of embolism directly. Furthermore, we can evaluate adjacent structures such aslung parenchyma, mediastinum, pleural and chest wall by pulmonary CTA. Another advantage of the pulmonary CTA is that it can beused to evaluate patients' response to treatment (10). In addition, shorter screening time prevents respiratory artifacts. Under the guidance of these advances, CTA has become a routine imaging modality to assess pulmonary vascularity in suspected PE (11).

Conventional venography has been used for the diagnosis of DVT for many years and still has a significant role in the evaluation of calf veins. Since it reveals the anatomical structure of the venous system, it is acceptedas the gold standard. However, the disadvantage of this method is that it is invasive, expensive, experiential, and requires contrast material. After the examination, complications such as phlebitis, allergic reaction, and DVT may develop (12).

Indirect CT venography, as in conventional venography, contrast material is injected from the dorsal vein in the foot and evaluated with axial sections. Baldt et al.investigated the effectiveness of direct CT venography in the diagnosis of lower extremity DVT and found that the sensitivity of direct CT venography was $100 \%$, and specificity was $96 \%$ compared to conventional venography (13). However, direct CT venography requires contrast media and is not routinely applied in practice (14).

Nowadays, conventional venography has been replaced by CDUS for the evaluation of the lower extremity venous system. CDUS, which is the first choice imaging method for the diagnosis of venous thrombosis due to its non-invasive, reproducible, easy tolerability, and low cost to the patient. The sensitivity of CDUS in femoro-popliteal venous thrombosis was $89-100 \%$; specificity was $99-100 \%$; the positive accuracy rate was $97 \%$,and the negative accuracy rate was reported as 94\%. There are many studies showing that CDUS is not sufficient in the diagnosis of calf and pelvic region DVT (13). Therefore, CDUS is accepted as a clinical standard method, although it is not a gold standard. There are some limitations of CDUS, which is considered a clinical standard. These limitations are obesity, soft-tissue edema, and suboptimal image quality. CDUS cannot be performed on immobilized patients such as cast, who are difficult to position; there is no acoustic window forthese reasons. Moreover, CDUS is inadequate to detect pelvic and abdominal thrombi (15).
Isolated DVT in the pelvic region is rare, with a thrombus of $0.5 \%$ to $4 \%(5,16)$. In their study with 61 patients, Taffoni et al. reported no isolated pelvic thrombus (17). It has been reported in the literature that thrombus in these regions is a risk factor for recurrent pulmonary embolism (18). Cham et al. reported that pelvic DVT was $11-30 \%$ and isolated DVT was $1 \%$ in PE (five In their study of 541 patients with suspected PE). They reported that all pelvic DVT affected other lower extremity veins, but one patient had isolated DVT in BMI (5). Goodman et al. have shown that isolated pelvic thrombi were only $1 \%-4 \%$ of patients with DVT (19). In the 105 series of PIOPED II, it was reported that only three patients (3\%) had isolated pelvic thrombi (20).

Indirect CTV applications were first introduced in 1998 by Loud et al. (2). Pulmonary arteries for the diagnosis of $\mathrm{PE}$ and deep venous system for the diagnosis of DVT can be monitored with a single imaging method with a single bolus contrast agent application. Many studies in the literature suggest that the addition of CTV in addition to CTA increases the diagnosis of VTE $(2,5,21)$. Although it is a noninvasive and fast method that does not require additional contrast media, ICTV has some disadvantages. Firstly, different protocols are used technically, and parameters such as section thickness, section spacing, scanning shape (helical or axial) have not been standardized yet.

Venous return is delayed in cases such as severe heart failure and atherosclerotic vascular disease. Delay of venous return may result in flow artifacts due to the mixing of non-opacified blood with opacified blood, and inadequate venous opacification may lead to false-negative results $(22,23)$. Another disadvantage of the method is the radiation dose received in ICTV. The effective radiation dose in ICTV is $7.05 \mathrm{mSv}$ (2.3-11.8), depending on the different protocols. The effective radiation dose of ICTV is $5.2 \mathrm{mSv}$ for the pelvis and $0.6 \mathrm{mSv}$ for the lower extremity (24).

High radiation dose in ICTV depends mainly on the imaging of the pelvic region. Kalva et al. reported that only two patients detected venous thrombus in the pelvic region in a study involving 2074 patients related to the radiation dose taken on the ICTV and therefore screening the pelvic region to reduce the dose of radiation causing the limitation on the ICTV was not very important (16).Load et al. stated that IVC and iliac veins can be shown by ICTV as an advantage to CDUS. They found abdominal and pelvic thrombosis in $12 \%$ and pelvic thrombus in $4 \%$ of patients. In the same study, they reported that they reduced the radiation dose by using a $5 \mathrm{~cm}$ interval. The use of a $5 \mathrm{~cm}$ interval reduces the radiation dose by $80 \%$, but thrombus can not detect in $40 \%$ (2).

CDUS is not effective in the diagnosis of DVT in patients with lower extremity gypsum, severe edema, obesity and intubation, and in areas where technical deficiencies such as pelvic and adductor regions are present. ICTV is not effective in detecting thrombus in patients with metallic implants. The addition of ICTV to pulmonary CTA can provide VTE 
diagnosis quickly and effectively with a single examination method. Filling defect alone is effective in detecting thrombus, and the addition of other diagnostic criteria does not increase its efficacy.

In conclusion, in this study, ICTV and CDUS were found to have statistically equal sensitivity and sensitivity in the diagnosis of lower extremity DVT in patients with suspected PE. ICTV can be used as an effective diagnostic method, especially in cases of severe edema in the lower extremities and the regio of pelvic and adductor where CDUS is limited.

\section{Conflict of Interestand Financial Status:}

Our study has not been financed by an institution and institution. In this study, there is no conflict of interest among the authors on any subject.

\section{REFERENCES}

1. Duwe KM, Shiau M, Budorick NE, Austin JH, Berkmen YM. Evaluation of the Lower Extremity Veins in Patients with Suspected Pulmonary Embolism: a Retrospective Comparison of Helical CT Venography and Sonography. AJR. 2000;175:15251531.

2. Loud PA, Katz DS, Bruce DA, Klippenstein DL, Grossman ZD. Deep venous thrombosis with suspected pulmonary embolism: detection with combined CT venography and pulmonary angiography. Radiology. 2001;219:498-502.

3. Anderson FA JR, Wheeler HB, Goldberg RJ, Hosmer DW, Patwardhan NA, Jovanovic B, et al. A population-based perspective of the hospital incidence and case-fatality rates of deep vein thrombosis and pulmonary embolism. The Worcester DVT Study. Arch Intern Med. 1991;151(5):933-938.

4. Loud PA, Katz DS, Klippenstein DL, Shah RD, Grossman ZD. Combined CT venography and pulmonary angiography in suspected thromboembolic disease: diagnostic accuracy for deep venous evaluation. AJR. 2000;174:61-65.

5. Cham MD, Yankelevitz DF, Shaham D, Shah AA, Sherman L, Lewis A, et al. Deep venous thrombosis: detection by using indirect CT venography. The Pulmonary Angiography-Indirect CT Venography Cooperative Group. Radiology. 2000;216(3):744751.

6. Well PS, Anderson DR, Rodger M, Jeffrey S. Ginsberg, Clive Kearon, Michael Gent, et al. Derivation of a simple clinical model to categorize patients probability of pulmonary embolism: increasing the modelsutility with the SimpliRED D-dimer. Thromb.Haemost. 2000;83:416-420.

7. Sandler DA, Martin JF. Autopsy proven pulmonary embolism in hospital patients: Are we detecting enough deep vein thrombosis? J R Soc Med. 1989;82(4):203-205.

8. Kruit WH, De Boer AC, Sing AK, Van Roon F. The significance of venography in the management of patients with clinically suspected pulmonary embolism. J Intern Med. 1991;230(4):333339.

9. Eze AR, Comerota AJ, Kerr RP, Harada RN, Domeracki F. Is venous duplex imaging an appropriate initial screening test for patients with suspected pulmonary embolism? Ann Vasc Surg. 1996;10(3):220-223.

10. Öztürk A, Çelenk Ç, Belet Ü, Polat V, Akan H. Tromboembolikhastalıkta alt ekstremitederinventrombozununindirekt BT venografive Doppler US iledeğerlendirilmesi.Tanı.Giriş. Rad.2002;8:139-144.
11. British Thoracic Society Standards of Care Committee Pulmonary EmbolismGuideline Development Group.British Thoracic Society guidelines for the management of suspected acute pulmonary embolism. Thorax. 2003;58:470-483.

12. Garg K, Mao J. Deep venous thrombosis: spectrum of findings and pitfalls in interpretation on CT venography. AJR. 2001;177:319-323.

13. Baldt MM, Zontsich T, Stümpflen A, Fleischmann D, Schneider B, Minar E, et al. Deep venous thrombosis of the lower extremity: efficacy of spiral CT venography compared with conventional venography in diagnosis. Radiology. 1996;200(2):423-428.

14. Katz DS, Loud PA, Bruce D, Gittleman AM, Mueller R, Klippenstein DL, et al. Combined CT venography and pulmonary angiography: a comprehensive review. Radiographics. 2002;22 Spec No:S3-19; discussion S20-4.

15. Guidelines on diagnosis and management of acute pulmonary embolism.Task Force on Pulmonary Embolism, European Society of Cardiology. Eur Heart J. 2000;21:1301-1336.

16. Kalva SP, Jagannathan JP, Hahn PF,Wicky ST. Venous thromboembolism: indirect CT venography during CT pulmonary angiography--should the pelvis be imaged? Radiology. 2008; 246:605-611.

17. Taffoni MJ, Ravenel JG, Ackerman SJ. Prospective comparison of indirect CT venography versus venous sonography in ICU patients. AJR. 2005;185:457-462.

18. Lim KE, Hsu WC, Hsu YY, Chu PH, Ng CJ. Deep venous thrombosis comparison of indirect multidetector CT venography and sonography of lower extremities in 26 patients. Clin Imaging 2004;28:439-444.

19. Goodman LR, Curtin JJ, Mewissen MW, Foley WD, Lipchik RJ, Crain MR, et al. Detection of pulmonary embolism in patients with unresolved clinical and scintigraphic diagnosis: helical CT versus angiography. AJR Am J Roentgenol. 1995;164(6):13691374.

20. PIOPED investigators. The value of the ventilation/ perfusion scan in acute pulmonary embolism: results of the Prospective Investigation of Pulmonary Embolism Diagnosis (PIOPED). JAMA 1990;263:2753-2759.

21. Ghaye B, Nchimi A, Noukoua CT, Dondelinger RF. Does multi-detector row CT pulmonary angiography reduce the incremental value of indirect CT venography compared with single-detector row CT pulmonary angiography? Radiology. 2006;240(1):256-262.

22. Moser KM. Venous thromboembolism. Am Rev Respir Dis 1990;141(1):235-249.

23. Huet Y, Lemaire F, Brun-Buisson C,Knaus WA, Teisseire B, Payen D, et al. Hypoxemia in acute pulmonary embolism. Chest 1985;88:829-836.

24. Begemann PG, Bonacker M, Kemper J, Guthoff AE, Hahn KE, Steiner $\mathrm{P}$, et al.Evaluation of the deep venous system in patients with suspected pulmonary embolism with multi-detector CT: a prospective study in comparison to Doppler sonography. J Comput Assist Tomogr. 2003;27(3):399-409. 